Edu Consilium: Jurnal BK Pendidikan Islam

Vol 2, No. 1, Februari 2021, hlm. 21 - 35
ISSN 2503-3417 (online)

ISSN 2548-4311 (cetak)

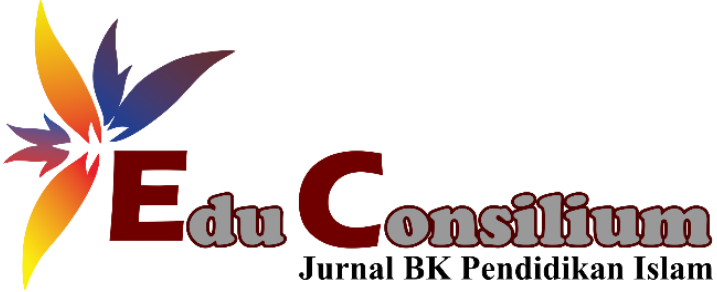

\title{
PERKEMBANGAN PSIKOSEKSUAL SANTRI PADA USIA DINI
}

\author{
Iswatun Hasanah $^{1^{*}}$, Imaniyatul Fithriyah ${ }^{2}$, Arina Mufrihah ${ }^{3}$ \\ ${ }^{1}$ Bimbingan dan Konseling Pendidikan Islam, Fakultas Tarbiyah, IAIN Madura \\ ${ }^{2}$ Bimbingan dan Konseling Pendidikan Islam, Fakultas Tarbiyah, IAI Al-Khairat Pamekasan \\ ${ }^{3}$ Bimbingan dan Konseling Pendidikan Islam, Fakultas Tarbiyah, IAIN Madura \\ *Iswatun Hasanah, iswatunhasanahiainmadura@gmail.com
}

\section{Keywords:}

Pesantren;

Psychosexual

developmen; Santri.

Abstract

Children especially at age 4 untill 6 years old have been introduced to formal and nonformal education where pesantren (islamic boarding school) is one of the most popular educatonal institutions in Indonesia. Commonly, pesantren is chosen by parents for their childs' education to learn both religious and modern knowledge. Furthermore, pesantren education will form students' independence. During their early-age development phase, santri (students who learn in pesantren) is remain similar to other children who experience psychosexual development; the two crucial stages are phallic and latent stage. Those periods would significantly affect santri's personality. The phallic stage is closely corresponded to genitalia as the specific erotogenic zone. Normally this stage is related to sexual identity and sexual orientation. Meanwhile, latent period is a time of childs' exploration into intellectual pursuits and social interactions, it is realized through self-disclosure towards interaction and adaptive socialization with their circumstances. On the other hand, parents are the important figure for children since they need to adapt to their psychosexual development phase including how to resolve several conflicts which may be dealed with them. Therefore, even though pesantren has a strong tradition in religious education, parents steady have main responsibility of their childs' education and guidance.
\end{abstract}

\begin{tabular}{ll}
\hline \hline & Abstrak: \\
\hline Kata Kunci: & Anak-anak usia dini terutama pada usia 4 hingga 6 tahun umumnya sudah mulai \\
Pesantren; & dikenalkan pada pendidikan formal dan non formal, salah satunya ialah pendidikan di \\
Psikoseksual; Santri & pesantren. Pesantren dipilih oleh orang tua agar anak dapat belajar pengetahuan agama \\
& dan pengetahuan umum, serta pembentukan kemandirian dan kedisiplinan yang \\
& diharapkan orang tua. Pada santri usia dini, fase perkembangan psikoseksual yang \\
& dilalui diantaranya adalah fase falik dan laten. Dua fase krusial yang sangat berpengaruh \\
& terhadap kepribadian anak pada masa mendatang. Pada fase falik kepuasan terletak di \\
& daerah kemaluan yang normalnya akan mmebentuk identitas dan orientasi seksual anak. \\
& Sementara pada fase laten kepuasan terletak pada aspek kognitif dan interaksi sosial \\
& yang terealisasi melalui keterbukaan diri untuk berinteraksi dan bersosialiasi dengan \\
& lingkungan secara baik. Kehadiran orang tua sangat dibutuhkan oleh santri untuk bisa \\
& melewati fase falik dan laten dengan baik dan menyelesaikan konflik pada dua fase \\
& tersebut. Maka dari itu, meski pesantren memiliki tradisi yang kuat dalam pendidikan \\
& agama, namun orang tua tetap memiliki tanggung jawab utama dalam pendidikan dan \\
& pembimbingan anak-anak mereka.
\end{tabular}

CEdu Consilium: Jurnal BK Pendidikan Islam

Bimbingan dan Konseling Pendidikan Islam

Institut Agama Islam Negeri Madura, Indonesia

\section{PENDAHULUAN}


Anak dengan kisaran usia 0 sampai 6 tahun disebut dengan anak usia dini, yang mana dalam psikologi perkembangan berada pada masa bayi dan kanak-kanak awal. Masa usia dini identik dengan masa emas dimana pada masa tersebut banyak hal penting yang terjadi dan tidak dapat terulang lagi dimasa berikutnya. Di masa inilah peran orang disekitarnya sangatlah dibutuhkan baik lingkungan keluarga dan pendidikan agar bisa membantu semua proses perkembangan anak secara tepat dan optimal dalam mengarahkan potensi kognisi, sosioemosi, skill maupun spiritual anak. Pada masa ini anak lebih banyak menuntut perhatian lebih/ekstra dari orang tua, kerena masa ini perubahan yang terjadi sangatlah pesat dan mudah dilihat serta diukur perubahannya. Perubahan yang terjadi dimulai dari perubahan fisik, kognitif, bahasa, maupun perkembangan emosi dan kepribadiannya.

Kondisi anak di usia dini tidak selalu sesuai harapan orang tua, tak jarang perkembangan anak mengalami masalah baik darisegi fisik, psikologis, ataupun dalam hal perkembangan psikoseksual. Masalah perkembangan pada fase usia dini dimungkinkan akan lebih mudah untuk dilakukan intervensi sehingga dimasa depan, anak tidak akan kesulitan dan dapat menjadi pribadi yang optimis dan dapat menerima dirinya dengan baik dengan segala kekurangan dan kelebihannya. Menurut hasil penelitian Prasetiawan (2019) manusia dengan pengalaman hidup positif yang terbentuk selama masa usia dini akan teraktualisasi dan teralisasi sepanjang hidupnya. Anak sampai usia 6 tahun akan mengalami masa emas dimana pada usia ini akan sensitif terhadap berbagai rangsangan yang menyebabkan mudahnya dalam meniru dan menerima rangsangan dari lingkungan sekitarnya.

Tahap pertumbuhan dan perkembangan fisik yang terjadi terutama otak pada masa bayi memiliki perkembangan yang luar biasa pesat yakni mencapai $80 \%$ dari keseluruhan perkembangan otak manusia (Rahman, 2005). Adapun bayi yang baru lahir telah mencapai perkembangan otar sekitar $25 \%$ dari perkembangan otak orang dewasa dan kesempurnaan perkembangan otak manusia 50\% dicapai hingga usia 4 tahun, $80 \%$ hingga usia 8 tahun dan selebihnya diproses hingga anak berusia 18 tahun. Dengan perkembangan otak yang berlangsung cepat perlu diimbangi dengan asupan gizi yang seimbang. Usia dini tidak hanya berkaitan dengan kemampuan kognitif tetapi juga pada unsur psikoseksual yang juga terdapat beberapa tahapan yang harus dilalui anak dan tahapan paling banyak dan paling penting berada di usia dini.

Berkaitan dengan masalah psikoseksual sebenarnya adalah membahas masalah tumbuh kembangnya kepribadian anak sejalan dengan pertumbuhan dan perkembangan fisik yang mana faktor seksualitas memainkan peranan kunci yang sangat berpengaruh pada ketiga hal tersebut. Selanjutnya berkait dengan teori perkembangan psikoseksual, Hariyanto (2010) 
menyatakan bahwa teori perkembangan psikoseksual Freud merupakan teori yang banyak memberikan kontribusi mengenai perkembangan dan mendapat kritik atau kontroversial dalam dunia psikologi. Freud menyatakan bahwa perkembangan yang dilalui anak terjadi dengan adanya tahapan di mana individu selalu mencari kesenangan energi dari id, dimana id beroperasi berdasarkan prinsip kenikmatan (pleasure principle). Energi psikoseksual digambarkan sebagai pendorong munculnya perilaku yang dilakukan oleh individu dalam kegiatan sehari-hari.

Kepribadian menurut Freud sebagian besar dibentuk pada usia lima tahun pertama. Lima tahun pertama kehidupan akan berpengaruh terhadap proses pembentukan kepribadian dan secara terus-menerus akan mempengaruhi perilaku individu di kemudian hari. Berdasarkan hasil penelitian ditemukan bahwasanya kehidupan manusia pada lima tahun pertama akan memberikan dampak yang luar biasa terhadap perkembangan sosial dan emosionalnya serta terjadinya pengalaman negatif pada usia ini akan mengganggu kesehatan mental anak (Cooper, 2009). Jika tahap-tahap psikoseksual mampu diselesaikan dengan baik serta konflik dapat teratasi tanpa meninggalkan trauma yang berarti, kemungkinan besar anak akan memiliki kepribadian yang sehat, begitupun juga sebaliknya jika pada usia dini anak mengalami masalah dalam proses perkembangan psikoseksualnya maka dikemudian hari dimungkinkan akan memiliki kepribadian yang tidak sehat.

Pada masa usia dini terutama di usia 4 sampai dengan 6 tahun, pada umumnya di masyarakat anak sudah mulai dikenalkan pada pendidikan formal atau non formal yakni pendidikan Kelompok Belajar (KB/ Pendidikan Anak Usia Dini (PAUD), pondok kecil, Madrasah, serta taman kanak-kanak (TK). Adapun salah satu jenis pendidikan yang juga menjadi pilihan banyak masyarakat yakni pendidikan di pesantren. Pesantren menurut Abdurrahman Mas'ud (dalam Ma'arif, 2015: 20) secara terminologis berasal dari kata "santri" yang bermakna mencari ilmu keislaman, sedangkan kata pesantren mengacu pada tempat tinggal santri dalam memperoleh ilmu, sedangkan kegiatan belajar, mengaji, dan ilmu agama serta menetap di tempat tersebut dengan waktu yang relatif lama di pesantren disebut dengan mondok/santri mukim

Pesantren menjadi pilihan orang tua dalam mempercayakan pendidikan anaknya, karena jika anak dipesantren mereka akan belajar pengetahuan agama dan pengetahuan umum, serta melatih anak-anaknya untuk mandiri dan anak tertib sesuai dengan ekspektasi orang tua. Tak jarang orang tua mulai memasukkan anak ke pesantren (mondok) di usia 4/5 tahun yang biasanya dikenal dengan sebutan pondok kecil, biasanya karena pekerjaan orang tua yang menjadi Tenaga Kerja Indonesia (TKI), karena aturan keluarga untuk mondok, 
ataupun alasan khusus lainnya (Fuaturosida, 2013), dimana orang tua lebih fokus pada perkembangan kognitif dan perilaku anak dan kurang memahami tentang perkembangan psikoseksual anak yang seharusnya mendapatkan perhatian khusus dari orang tua serta dibawah pengawasan orang tua.

Mondok di usia dini sangat memungkinkan terjadinya masalah psikologi dan psikoseksual, bahkan terdapat hasil penelitian pada anak yang dikirim ke asrama di usia dini diketahui masalah hilangnya kedekatan dengan orang tua dan trauma-trauma psikologis selama tinggal di asrama (Scaverian, 2011). Sebagaimana hasil penelitian Siti Mumun Muniroh (2014) mengenai Psikologi Santri Usia Dini yang memperoleh kesimpulan bahwa tipe pengasuhan yang diterapkan di pondok pesantren Salafiyah Syafiiyah terhadap santri anak usia dini dikelompokkan menjadi dua yakni otoriter dan demokratis. Jenis pengasuhan yang diterapkan dan latar belakang motivasi anak mondok dipesantren akan menunjukkan perkembangan yang berbeda terhadap anak, baik pada cara berpikir, kecakapan psikomotorik, kemampuan bersosialisasi, kemampuan dalam menghafal, penguasaan ilmu dan lainnya. Idealnya anak usia dini tinggal dan mendapat pendidikan dari orang tua terlebih dalam hal perkembangan psikoseksual anak. Orang tua memberikan pendidikan sedari dini tentang pengetahuan dan perkembangan psikologis, fisik, dan psikoseksual anak.

Sebagaimana juga hasil penelitian Hanafi, Imam tentang "Dinamika Psikologis Anak di Pondok Cilik Maktab Nubdzatul Bayan Al-Majidiyah Palduding Plakpak Pagentenan Pamekasan (2017)". Penelitian tersebut dilakukan pada santri dengan rentang usia 6-12 tahun yang dapat disimpulkan bahwa perkembangan psikologis anak bervariasi sesuai tahapan perkembangan, yang mana terdapat perkembangan yang sesuai dan tidak sesuai dari masingmasing-masing aspek perkembangan mulai dari perkembangan fisik, emosi, sosial, kepribadian, dan perkembangan minat beragama. Perkembangan yang bervariasi tersebut didukung oleh berbagai faktor diantaranya gizi anak, keadaan fisik (kesehatan), kemampuan penyesuaian diri, materi, pengasuhan oleh ustad, penanaman nilai, dan latar belakang keluarga.

Orang tua sebagai keluarga inti berperan penting dalam pertumbuhan dan perkembangan anak. Keluarga merupakan subsitem yang saling berinteraksi dan berkaitan serta memiliki pengaruh antara yang satu dengan yang lain. Kedua orang tua merupakan peletak dasar pertama pada usia ini dalam hal pendidikan, akhlak, terbentuknya konsep diri, dan penanaman kebiasan-kebiasan (Hasan, 2006: 19). Kelekatan anak dengan orang tua sangat dibutuhkan dan berkaitan dengan tipe pengasuhan yang dilakukan oleh orang tua. Orang tua akan mengembangkan aturan yang harus disepakati bersama untuk menghindari 
hukuman-hukuman yang malah akan membuat anak menjadi penakut, pemalu dan tidak bahagia. Menurut Diana Baumrind (Santrock, 2012: 290) terdapat empat tipe pengasuhan yakni; pengasuhan otoritarian, otoritatif, yang melalaikan, dan pengasuhan yang memanjakan.

Tipe pengasuhan otoritarian bercirikan memberikan batasan dan hukuman serta cenderung memaksa anak untuk mematuhi aturan secara kaku tanpa memberikan penjelasan dan tidak memberi kesempatan kepada anak untuk saling bertukar pendapat. Anak yang diasuh dengan gaya seperti ini memiliki kecenderungan tidak bahagia, kurang berinisiatif, keterampilan komunikasi yang kurang baik dan mudah merasa cemas dalam menghadapi masalah. Tipe pengasuhan yang kedua yakni otoritatif (authoritative parenting) yakni anak didorong untuk mandiri namun terdapat batasan dan kendali terhadap perilaku anak. Orang tua mengajak anak untuk berdiskusi atas perilaku mereka. Anak-anak dalam pengasuhan ini seringkali terlihat bahagia, percaya diri, kooperatif dan mampu mengelola emosi dengan baik.

Sedangkan tipe pengasuhan yang melalaikan yakni pengasuhan yang mana orang tua cenderung mengabaikan atau tidak terlibat dalam kehidupan anak. Anak dalam pengasuhan ini kurang memiliki kendali terhadap dirinya, cenderung rendahnya harga diri yang dimiliki, kurang matang dan ketika memasuki masa remaja menunjukkan perilaku membolos dan melakukan pelanggaran. Berbanding terbalik dengan jenis pengasuhan sebelumnya, untuk tipe pengasuhan yang memanjakan (indulgent parenting) yakni orang tua kurang memberikan kendali terhadap kondisi anak. Anak akan dibiarkan melakukan segala sesuatu atas kemauan dan kedendak mereka sendiri. Hasilnya anak cenderung sulit mengendalikan perilakunya sendiri, kurang menghormati orang lain, tidak patuh, egosentris dan kesulitan ketika berteman dengan teman sebaya nya.

Kelekatan yang terjadi antara anak dan ibunya sangatlah penting pada tahun pertama kehidupan agar anak memiliki harapan dan kepercayaan bahwa bukan hanya rahim ibu yang menjadi tempat ternyaman untuk tinggal tetapi dunia lebih indah dan menyenangkan untuk dihuni dan hidup. Kelekatan tidak terjadi secara tiba-tiba namun perlu dibentuk dan dikembangkan melalui serangkaian proses dan peristiwa yang terjadi antara kedua orang tua dan anak. Salah satunya dalam penelitian Marshal Klaus dan John Kennel (dalam Desmita, 2009: 122) yang diketahui bahwa kelekatan bisa terjadi karena adanya kontak fisik diantara keduanya dan hal ini sangatlah penting untuk pembentukan pola hubungan orang tua dan anak dikemudian hari. Adapun dampak interaksi tersebut akan membuat perilaku yang lebih hangat dan membuat ibu tidak menyiksa anaknya serta lebih peka terhadap kebutuhan anak. Sebagaimana hasil penelitian Wuryantari, Tina (2015) diketahui bahwa terdapat hubungan 
yang positif pada anak berusia 4-6 tahun antara kelekatan aman dengan tempramen sebesar 55, 4\%. Kelekatan anak dengan objek pengganti yang tidak memiliki hubungan secara biologis dapat mempengaruhi perilaku tempramen, hal ini bisa disebabkan karena kurangnya komunukasi, kurang sensitive dan responsif terhaadap kebutuhan anak.

\section{METODE}

Dalam artikel ini menggunakan study literatur (library research) dengan menggunakan buku, jurnal atau literatur lainnya sebagai objek penelitian yang utama. Study literatur atau sering juga disebut dengan riset kepustakaan dilaksanakan untuk mengkaji dan menjawab permasalahan mengenai psikoseksual santri pada usia dini secara mendalam dan menyeluruh menggunakan bahan pustaka yang relevan. Adapun pustaka yang dikaji berupa hasil penelitian baik skripsi, tesis maupun disertasi, jurnal, dan buku-buku, serta dokumen cetak/elektronik yang relevan untuk membahas persoalan terkait.

Dalam riset kepustakaan (library research) ini, peneliti tidak terjun secara langsung ke lapangan dikarenakan data diperoleh dari sumber pustaka yang kemudian dibaca, dicatat, dan dianalisis. Dalam hal penelitian kepustakaan ini, peneliti mencari data kepustakaan berupa teori mengenai psikoseksual Sigmund Freud. Adapun alasan peneliti menggunakan riset kepustakaan dikarenakan perlu dilakukan studi pendahuluan untuk memahami psikoseksual santri pada usia dini dan bahan pustaka terkait teori psikoseksual Sigmund Freud sudah cukup handal dalam menjawab persoalan tersebut.

\section{HASIL}

Tahapan perkembangan psikoseksual akan berubah-ubah seiring kematangan anak. Setiap tahapan menghasilkan sejumlah perasaan frustasi, konflik, dan kecemasan. Jika hal ini tidak dapat diselesaikan secara baik, perkembangan normal dapat terganggu dan anak dapat terus terfiksasi atau tertahan pada tahapan tertentu. Sebagai contoh, menurut Freud ada orang yang terfiksasi pada tahap oral yang terjadi pada tahun pertama kehidupan manusia, saat bayi menghayati dunianya melalui mulut. Sebagai orang dewasa, mereka akan mencari kepuasan oral dengan merokok, makan berlebihan, menggigit kuku atau menggigit ujung pensil, lainnya menjadi sangat lekat terhadap orang lain dan tidak mandiri.

Namun bagi Freud, tahapan yang paling penting dalam pembentukan kepribadian adalah tahap phallic (oedipal) yang berlangsung dari usia 4-5 (6) tahun. Selama tahap ini Freud beranggapan bahwa anak memiliki keinginan yang tidak ia sadari untuk memiliki orang tua yang jenis kelaminnya berbeda dan menyingkirkan orang tua yang jenis 
kelaminnya sama dengan dirinya. Anak seringkali berkata"aku akan menikah dengan ayah/ibu apabila besar nanti. Fenomena ini disebut oedipus complex, dari legenda Yunani yang secara tidak sengaja membunuh ayahnya dan menikahi ibunya. Berikut ini adalah model atau tahapan perkembangan kepribadian menurut Freud:

\begin{tabular}{|c|c|c|c|}
\hline Tahapan & Usia & Pusat Erotis & Pengalaman \\
\hline Oral & $0-1$ & Mulut & Menyusu dan Penyapihan dari menyusu \\
\hline Anal & $1-3$ & Anus & $\begin{array}{l}\text { Toilet training (pembiasaan dalam } \\
\text { mengatur buang air kecil dan besar) }\end{array}$ \\
\hline Phallik & $4-5$ & Alat Kelamin & $\begin{array}{l}\text { Identifikasi kepada model peranan orang } \\
\text { dewasa untuk jenis kelamin yang sama, } \\
\text { dan belajar mencintai lawan jenis }\end{array}$ \\
\hline Latensi & $6-12$ & Tidak ada & $\begin{array}{l}\text { Memperluas interaksi sosial dengan } \\
\text { lingkungan sekitar, utamanya teman } \\
\text { seusianya }\end{array}$ \\
\hline Genital & $12 \geq$ & Genital & $\begin{array}{l}\text { Membangun hubungan yang lebih intim } \\
\text { (akrab) dengan pasangan hidupnya, dan } \\
\text { memberikan kontribusi pada masyarakat } \\
\text { melalui bekerja serta pemunculan } \\
\text { perilaku dan trauma dari fase } \\
\text { sebelumnya. }\end{array}$ \\
\hline
\end{tabular}

a. Fase oral

Fase oral merupakan tahap pertama dalam kehidupan manusia dimana bayi berkomunikasi dengan ibunya dengan cara menyusu, seluruh hidup anak bergantung pada ibunya. Bayi membangun relasi pertama untuk mencapai kepuasan dengan menghisap dan menelan. Daerah mulut menjadi tempat utama aktivitas atau pusat kepuasan seksual yang dipilih oleh insting seksual, mulut adalah era erotis yang berperan dalam pemenuhan kepuasan pada diri bayi tersebut. Kepuasan ini biasanya bayi dapat dengan menghisap payudara ibunya, tidak hanya dengan menghisap payudara ibunya terkadang bayi juga menghisap ibu jarinya sendiri. Kenikmatan atau kepuasan tidak hanya menghisap namun juga dapat diperoleh dari rangsangan terhadap bibir, rongga mulut, dan kerongkongan. Tingkah laku menggigit dan mengunyah (ketika gigi sudah tumbuh) serta menelan dan memuntahkan (kalau makanan tidak memuaskan) didalam fase ini terlihat bahwa hanya id yang terbentuk dalam kepribadian bayi, peran ibu sangat penting dalam fase ini karena ibu harus memastikan kebutuhan oral bayi sudah terpenuhi dengan baik atau tidak baik melalui air susu atau makanan. Kepuasan dan ketidakpuasan pada masa oral sangat berpengaruh di masa selanjutnya. Masalah yang muncul pada fase 
oral yang paling umum terjadi adalah waktu menyapih (berhenti minum air susu ibu) pada bayi.

Menyapih adalah pengalaman utama dalam tahap perkembangan psikoseksual mulut bayi, perasaan kehilangan pertama mereka akibat kehilangan keintiman fisik saat menyusui di payudara ibu. Namun, menyapih mampu meningkatkan kesadaran diri pada bayi bahwa tidak seterusnya lingkungan selalu sesuai dengan keinginannya, dan dari hal tersebut bayi dapat mempelajari gratifikasi/ kesenangan yang tertunda, mengarah pada pembentukan kapasitas diri untuk menunjukkan perilaku mandiri (kesadaran akan batasbatas diri) dan kepercayaan diri (perilaku yang mengarah pada rasa puas).

b. Fase anal

Fase Anal merupakan fase kedua dimana Freud meyakini bahwa fokus utama dari kenikmatan berada pada pengendalian saluran air kencing dan buang air besar. Dubur merupakan daerah pokok aktifitas dinamik, kateksis dan anti kateksis berpusat pada fungsi eliminer (pembuangan kotoran). Konflik utama pada tahap ini adalah kegiatan pelatihan toilet yang mana anak belajar mengendalikan saluran pembuangannya. Kesuksesan pada tahap ini sangatlah bergantung pada pendekatan yang dilakukan orang tua terhadap pelatihan toilet. Pemberian reward pada saat yang tepat dapat mendorong dan memberikan hasil positif dalam terlaksananya pelatihan toilet sehingga anak menjalaninya dengan senang hati dan bertanggung jawab tanpa beban (Hariyanto, 2010).

Pada fase ini anak mulai mengetahui dan memahami cara menghilangkan kotoran dari tubuhnya. Perasaan jijik dan ingin tahu membuat mereka belajar banyak hal dari lingkungan, benar dan bersih semuanya bergantung dari latihan dan bantuan yang diberikan oleh lingkungan disekitarnya terutama ibu sebagai orang terdekat si anak. Peran ibu sangat dibutuhkan sebagai bentuk awal dari belajar memuaskan id dan superego sekaligus dampak dari toilet training terhadap kepribadian di masa depan. Dengan ketelatenan ibu dalam mendampingi anak nantinya anak akan memahami pentingnya buang air kecil dan besar di tempat yang tepat. Terdapat beberapa yang bisa dilakukan oleh orang tua dalam pelatihan toilet ini yang mana ketiga cara tersebut akan memberikan dampak yang berbeda terhadap anak. 


\begin{tabular}{|c|c|}
\hline $\begin{array}{l}\text { Sikap keras dan sering } \\
\text { menghukum pada saat } \\
\text { melakukan kesalahan dalam } \\
\text { buang air kecil atau besar }\end{array}$ & $\begin{array}{l}\text { Memunculkan perilaku anak akan mudah jijik atau } \\
\text { bersikap berlebihan kepada kebersihan dan } \\
\text { ketertiban, penakut, kaku terhadap aturan, } \\
\text { cenderung tidak kreatif, menunjukkan perilaku } \\
\text { egosi dan kejam/ kasar. }\end{array}$ \\
\hline $\begin{array}{l}\text { Selalu memuji dalam kondisi } \\
\text { apapun perilaku yang } \\
\text { ditampilkan anak }\end{array}$ & $\begin{array}{l}\text { Memunculkan perilaku pada anak yakni Selalu } \\
\text { ingin mendapatkan perhatian dari orang lain/ingin } \\
\text { dipuji, cenderung kurang mandiri, serta manja dan } \\
\text { suka menyuruh orang lain melakukan sesuatu sesuai } \\
\text { keinginan. }\end{array}$ \\
\hline $\begin{array}{l}\text { Sikap pengertian terhadap } \\
\text { kondisi anak. Memuji jika } \\
\text { menunjukkan perilaku positif } \\
\text { dalam buang air keci. Besar } \\
\text { serta memahami dan } \\
\text { mengarahkan jika anak } \\
\text { kesulitan dalam toilet training }\end{array}$ & $\begin{array}{l}\text { Memunculkan perilaku anak akan mudah } \\
\text { beradaptasi, kondisi egonya akan berkembang } \\
\text { dengan wajar }\end{array}$ \\
\hline
\end{tabular}

c. Fase Phallic

Fase Falik (Fase Phallic) dimana fokus utama di fase ini adalah libido pada alat kelamin. Perkembangan terpenting dalam fase ini yaitu munculnya oedipus complex yang terjadi bersamaan dengan castration anxiety (pada laki-laki) dan penis envy (pada perempuan). Odipus kompleks merupakan kateksis objek seksual kepada orang tua yang berbeda jenis serta permusuhan terhadap orang tua dengan jenis kelamin sama. Anak laki-laki ingin memiliki ibunya dan menyingkirkan ayahnya; sebaliknya anak perempuan ingin berdekatan dan memiliki ayahnya dan merasa tersaingi dengan keberadaan ibu dalam mendapatkan perhatian Ayahnya. Pada awalnya baik anak perempuan maupun laki-laki memiliki kedekatan dan kecintaan kepada ibunya lebih besar karena telah memenuhi semua kebutuhan mereka dan memandang ayah sebagai saingan dalam memperebutkan kasih sayang ibu. Namun, bedanya adalah; pada anak laki-laki persaingan dengan ayahnya itu akan mengakibatkan dia cemas penisnya akan dipotong sang ayah, sedangkan pada anak perempuan, rasa cinta kepada ibunya segera berubah menjadi kecewa setelah mengetahui bahwa kelaminnya berbeda dengan anak laki-laki sehingga ibunya dianggap bertanggung jawab atas kastrasi kelaminnya (Alwisol, 2008:31-32). 
Pada tahap ini, anak cenderung masih bersikap "selfish" sikap yang tidak memperdulikan dan memperhatikan orang lain. Perkembangan gejala-gejala psikologis pada tahap phalik disajikan pada tabel berikut ini.

\begin{tabular}{|c|c|c|}
\hline Gejala & Pengertian & Keterangan \\
\hline $\begin{array}{l}\text { Anak perempuan } \\
\text { menunjukkan } \\
\text { sikap iri hati } \\
\text { terhadap anak } \\
\text { jenis kelamin laki- } \\
\text { laki (penis envy) }\end{array}$ & $\begin{array}{lrr}\text { Perilaku } & \text { cemburu } & \text { anak } \\
\text { perempuan } & \text { terhadap } & \text { anak } \\
\text { laki-laki } & \text { karena } & \text { secara } \\
\text { anatomi } & \text { seksual } & \text { pada } \\
\text { perempuan } & \text { tidak } & \text { sama } \\
\text { dengan laki-laki. } & \text { Anak } \\
\text { perempuan akan } & \text { merasa } \\
\text { tidak senang dan cenderung } \\
\text { mencela anatominya sendiri, } \\
\text { karena } & \text { dipandang } \\
\text { "dificiency" } & \text { (terdapat } \\
\text { kekurangan). }\end{array}$ & $\begin{array}{l}\text { Pendampingan ibu sangat } \\
\text { dibutuhkan untuk membantu } \\
\text { anak dalam memahami jenis } \\
\text { kelamin dan anatominya yang } \\
\text { berbeda. }\end{array}$ \\
\hline Masculine protes & $\begin{array}{lr}\text { Rasa cemburu pada jenis } \\
\text { kelamin } \\
\text { menyebabkan } & \text { laki-laki } \\
\text { menunjukkan } & \text { anak } \\
\text { menyamai anak laki-laki, } \\
\text { misalnya dalam bermain dan } \\
\text { berpenampilan. }\end{array}$ & $\begin{array}{l}\text { Kondisi terjadi karena orang } \\
\text { tua atau lingkungan sekitar } \\
\text { kurang menghargai jenis } \\
\text { kelamin perempuan, atau } \\
\text { pengharapan orang tua } \\
\text { terhadap jenis kelamin laki- } \\
\text { laki serta penampilan ibu yang } \\
\text { cenderung kurang feminism. }\end{array}$ \\
\hline Electra Complex & $\begin{array}{l}\text { Perilaku anak perempuan } \\
\text { yang kagum dan mencintai } \\
\text { ayahnya, hal ini disebabkan } \\
\text { karena perempuan tidak } \\
\text { memiliki anatomi tubuh yang } \\
\text { sama dengan laki-laki. }\end{array}$ & $\begin{array}{l}\text { kondisi tersebut terjadi karena } \\
\text { kelekatan anak perempuan } \\
\text { cenderung lebih besar dengan } \\
\text { ayahnya yang lebih diam dan } \\
\text { tidak memarahi anak, } \\
\text { dibandingkan dengan ibunya. }\end{array}$ \\
\hline Oedipus Complex & $\begin{array}{l}\text { Perasaan cinta anak laki-laki } \\
\text { terhadap ibunya dan tertarik } \\
\text { secara seksual dengan ibunya } \\
\text { serta menjauhi ayahnya } \\
\text { karena dianggap saiangan/ } \\
\text { akan merebut perempuan } \\
\text { yang disukainya. Oedipus } \\
\text { Complex ini melahirkan } \\
\text { sikap ambivalensi pada anak } \\
\text { (konflik internal), yaitu sikap } \\
\text { mendua antara membenci } \\
\text { ayah dengan keinginanya }\end{array}$ & $\begin{array}{l}\text { Gejala ini terjadi karena } \\
\text { biasanya Ibu yang sedari kecil } \\
\text { mengurus dengan penuh kasih } \\
\text { sayang, ayah lebih } \\
\text { menyibukkan diri dengan } \\
\text { pekerjaannya di luar, serta } \\
\text { ayah terlalu keras atau kurang } \\
\text { memberikan kasih sayang } \\
\text { kepada anak laki-lakinya. } \\
\text { Gejala oedipus ini (sikap } \\
\text { memusuhi ayah) akan } \\
\text { menyebabkan anak merasa }\end{array}$ \\
\hline
\end{tabular}




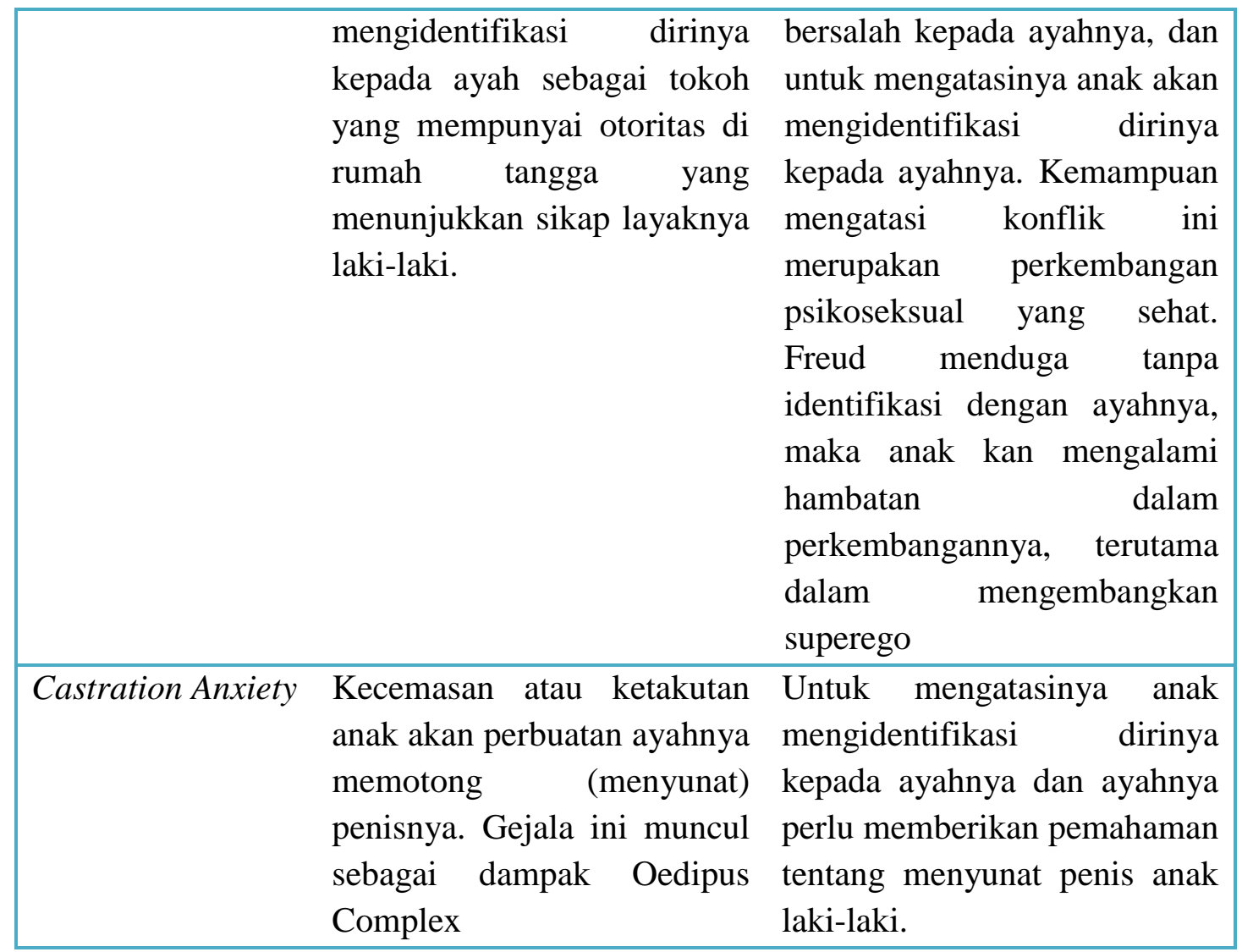

d. Fase Laten

Fase yang keempat yakni Fase Laten dimana pada periode ini memiliki ciri-ciri bahwa dorongan libidinal biasanya mengalami represi yang cukup efektif. Dorongan libidinal pada saat ini seolah "tidur" dan akan bengkit lagi dengan kekuatan penuh kelak di masa pubertas tiba. Selajutnya dikatakan Arif (2006:66) bahwa terjadi perkembangan kognitif dan sosialisasi anak yang pesat. Rasa ingin tahu anak sangat besar tentang berbagai hal. Oleh karena itu penting sekali orang tua memenuhi rasa ingin tahu dari anak tersebut. Usaha yang dapat dilakukan adalah dengan menyediakan pendidikan yang baik untuk memenuhi kebutuhan anak. Anak pada fase laten mulai memiliki kesiapan dalam belajar dan keinginan untuk berinteraksi dengan lingkungan sekitarnya. Anak mulai terbuka untuk menerima keberadaan orang baru/ teman baru.

e. Fase Genital

Fase selanjutnya adalah Fase Genital yakni fase tahap akhir perkembangan psikoseksual. Fase Genital berada sekitar usia 12 sampai dewasa dimana pemunculan kembali hasrat seksual yang di represi pada fase sebelumnya seperti pada fase oral, anal, phalik dan laten dan dari hasil semuanya itu berpengaruh pada fase ini. Pada fase ini pula seorang individu akan mengembangkan minat seksual yang kuat pada lawan jenis. Pada 
fase ini seseorang akan mengalami perubahan yang sangat cukup signifikan dalam diri dan dunianya. Tinggi dan berat badannya akan meningkat tajam. Ciri-ciri seksual primer dan sekunder akan mulai muncul. Dorongan libidinal dalam fase ini akan meningkat dengan pesat (Arif, 2006).

Pada fase ini, terjadi kematangan alat reproduksi pada anak dan anak juga mulai muncul rasa tertarik terhadap lawan jenis, dan ingin membangun hubungan yang lebih intim bersama orang lain. Hal ini berarti individu mendapatkan kepuasan dari stimulasi dan manipulasi tubuhnya sendiri, sedangkan orang lain di kateksis hanya karena membantu memberikan bentuk-bentuk tambahan kenikmatan jasmani bagi sang anak pada tahap ini semuanya sudah di dalam bentuk cinta yakni ada yang bersifat narsisitik (seperti anak mulai ada perasaan cinta kepada lawan jenisnya), dimana masih ada perasaan malu yangdi biasa kenal dengan cinta monyet dan ada bersifat altruistik (keinginan untuk berkorban pada yang lain). Setelah mencapai masa adolesen atau masa dewasa awal terjadilah perkembangan kateksis terjadi transformasi kepribadian terdorong oleh kedua motif misalnya sebagian cinta diri sendiri di salurkan kepada pilihan obyek yang sebenarnya misalnya anak remaja sudah mulai mencintai lawan jenisnya karena terdorong oleh motif altruistik, dan muncullah berbagai hal yang bersifat sosial seperti ada ketertarikan seksual dan perencanaan karir,dll.

\section{PEMBAHASAN}

Pembahasan perkembangan psikoseksual anak yang mondok di usia dini mencakup deskripsi perkembangan di setiap fase perkembangan psikoseksual dihubungkan dengan realitas anak yang mondok di usia dini. Setiap fase perkembangan yang tidak tertangani dengan baik serta meningglkan trauma masa lalu, akan menimbulkan konsekuensi yang akan berpengaruh terhadap kepribadian santri di masa yang akan datang. Santri usia dini yang mulai dikenalkan dengan dunia pesantrean biasanya berada pada rentang usia 4 atau 5 tahun. Orang tua meyakini bahwa anak harus sedari dini belajar ilmu agama dan pengetahuan pada pihak yang mumpuni dalam bidangnya atau karena kesibukan orang untuk mendampingi anak dalam belajar.

Santri usia dini di pondok pesantren akan mulai disiapkan dan dikenalkan tentang belajar ilmu agama dan pendidikan umum meskipun tanpa orang tua disampingnya serta mulai belajar untuk mandiri. Anak yang mondok sejak usia dini biasanya berada pade fase ketiga yakni fase falik karena berada di pondok pesantren akan jarang bertatap muka dan berkomunikasi dengan orang tua, dan hal ini akan menyebabkan anak akan sedikit demi 
sedikit kehilangan figur orang tua baik ibu atau bapak serta kelekatan terhadap keduanya, kondisi tersebut dapat menjadi penyebab konflik internal baik secara psikologis maupun terganggunya perkembangan psikoseksual yang berpengaruh pada kepribadian anak misalnya anak merasa tidak diperhatikan oleh tua, merasa diabaikan oleh orang tua, atau bahkan merasa tidak disukai oleh orang tua.

Kelekatan yang sudah terjalin antara orang tua dan anak di rumah tidak begitu saja bisa mendekatkan anak dengan figure pengganti dipesantren baik itu pengurus ataupun santri senior nya. Semua butuh waktu dan proses yang cukup lama yang mana kelekatan anak dengan figure pengganti disini akan memberikan dampak positif dan negatif. Adapun dampak positifnya yaitu dengan pengasuhan yang tepat dapat memberikan kenyamanan dan keamanan terhadap anak namun dampak negatifnya yaitu meningkatnya perilaku tempramen dan semakin luntur hubungan orang tua dan anak. Kelekatan yang sudah terbentuk dan berkembang akan menghilang seiring dengan tinggalnya anak dengan orang lain dan pengasuhan sudah tidak lagi berada pada orang tuanya. Anak yang tinggal di pesantren (mondok) dan diasuh oleh santri yang senior dan pengurus kecenderungan akan memperhatikan kebutuhan anak secara fisik. Misalnya kebutuhan akan makan, minum, pakaian bersih, sedangkan kebutuhan secara psikis dan psikosesksual sukar untuk dipenuhi dan diperhatikan oleh pengasuh/ santri senior karena beberapa alasan misalnya, banyaknya anak yang perlu di urus dan kelekatan anak dengan pengasuh/ santri senior.

Di pondok pesantren, santri usia dini akan belajar dengan teman jenis kelamin yang sama, penanggung jawab, atau bahkan kakak tingkat juga jenis kelamin sama (baik pada pondok laki-laki ataupun perempuan). Perkembangan psikoseksual pada fase ini santri akan melakukan Identifikasi dan mencintai untuk memenuhi kepuasan libido anak yang dilakukan pada orang berjenis kelamin yang sama dengan anak. Anak mencintai lawan jenisnya dan mengidentifikasi sesama jenisnya, sedangkan di pondok pesantren santri akan bertemu, beraktifitas, dan diasuh oleh orang dengan jenis kelamin yang sama sehingga jika anak tidak bisa menyelesaikan masalah pada fase tersebut dengan baik maka dimungkinkan anak akan mencintai dan mengindentifikasi sesama jenis.

Masalah perkembangan psikoseksual pada fase falik tersebut akan berdampak terhadap kepribadian anak dalam memuaskan kebutuhan seksualnya di fase genital, karena pada fase genital akan muncul perilaku-perilaku yang di represi di fase sebelumnya. Adapun masalah-masalah psikoseksual yang tidak terselesaikan dengan baik yakni munculnya orientasi seksual yang berbeda dengan masayarakat pada umumnya yakni homoseksual, transgender, lesbian, dan orientasi seksual lainnya. Selain berdampak terhadap orientasi 
seksual anak, juga berdampak terhadap kepercayaan diri dan semangat anak dalam memperoleh apa yang ingin diperjuangkan untuk ia miliki secara pribadi, misalnya pasangan hidup.

Selanjutnya adalah fase laten yang mana pada fase ini secara kognitif anak ingin belajar banyak hal dan rasa ingin tahunya tinggi. Kurikulum yang menyajikan pembelajaran beragam bisa memenuhi kebutuhan anak untuk memenuhi rasa ingin tahunya yang tinggi. Anak pada fase ini akan lebih aktif secara vokal, yakni banyak bertanya tentang banyak hal yang ditemuinya. Anak yang berada di pondok, diarahkan untuk patuh dengan apa yang disampaikan oleh gurunya serta mengikuti aturan-aturan di pondok pesantren secara tertib. Masalah yang muncul pada fase ini jika anak tidak mendapatkan intervensi dan menangani dengan baik maka akan muncul konflik dalam diri anak yakni ingin memuaskan rasa ingin taunya tetapi harus dibatasi dengan aturan yang harus ia patuhi. Kebutuhan yang di represi pada tahap ini kemungkinan akan cenderung muncul difase genital dengan wujud perilaku melanggar aturan, tidak selaras dengan lingkungan sekitar, atau bahkan bisa menunjukkan perilaku ekstrem yakni agresif dan kaku dalam menghadapi masalah yang ia temui.

Sedangkan dalam hal interaksi sosial, kebutuhan anak untuk menjalin interaksi sosial dengan lingkungan sekitarnya akan terbatas dalam ruang lingkup ruangan atau pondok yang ia tinggali. Jadi masalah yang muncul pada fase laten berkaitan dengan perkembangan psikoseksual anak yakni cenderung mengalami konflik dalam memuaskan kebutuhan rasa ingin tahu dan interaksi sosialnya, dan dalam jangka panjang dapat berakibat terdahap perkembangan kognitif anak dan kemampuan sosial dengan lingkungan sekitarnya.

\section{SIMPULAN}

Perkembangan psikoseksual menurut Freud terdiri dari 5 fase yakni fase oral, anal, falik, laten, dan genital. Lima tahap perkembangan tersebut memiliki kontribusi terhadap perkembangan kepribadian anak dan konflik di setiap fase perkembangan yang tidak terselesaikan dengan baik akan menyebabkan masalah pada kepribadian anak. Perkembangan psikoseksual santri pada usia dini yakni pada fase falik dan laten memiliki kondisi yang tidak ideal, yakni pada fase falik santri membutuhkan sosok orang tua yang diidentifikasi untuk jenis kelamin sejenis dan dicintai untuk jenis kelamin lawan jenis. Pada fase laten kebutuhan akan pemuasan rasa ingin tahu dan interaksi sosial pada santri kecenderungan berada pada kondisi represif. Pondok pesantren yang memiliki aturan ketat terhadap perilaku santri yakni santri harus patuh terhadap perintah ataupun saran dari guru akan menyebabkan konflik 
internal terhadap pemuasan kebutuhan di fase ini. Begitupun dalam hal kebutuhan akan interaksi sosial santri yang terbatas di lingkungan pondok pesantrean.

Kehadiran orang tua sangat dibutuhkan oleh santri, untuk bisa melewati fase falik dan laten dengan baik. Pelimpahan tanggung jawab untuk pengasuhan dan pendidikan santri pada usia dini kepada pondok pesantren kecenderungan tidak bisa menggantikan orang tua dalam memberikan pendidikan sedari dini pada santri, terutama dalam memperhatikan aspek perkembangan psikoseksual santri. Dua fase yang sangat krusial terhadap kepribadian santri membutuhkan kehadiran orang tua untuk bisa melewati fase falik dan laten dengan baik dan menyelesaikan konflik pada dua fase tersebut. Maka dari itu, meski pesantren memiliki tradisi yang kuat dalam pendidikan agama, namun orang tua tetap memiliki tanggung jawab utama dalam pendidikan dan pembimbingan anak-anak mereka.

\section{DAFTAR RUJUKAN}

Alwisol. (2008). Psikologi Kepribadian. Malang: UPT Penerbitan Universitas Muhammadiyah Malang.

Arif, I. S. (2006). Dinamika kepribadian, gangguang dan terapinya. Bandung: Refika Aditama.

Cooper J.L, M. R. (2009). Social- Emotional Development In Early Childhood: What Every Policy Maker Should Know. USA: Columbia University.

Desmita. (2009). Psikologi Perkembangan. Bandung: Remaja Rosdakarya

Fuaturosida, R. (2013). Attachment Anak Usia Dini Di Pondok Pesantren. Jurnal Psikologi Islam (JPI), Volume 10 Nomor 2.

Hanafi, I. (2017). Dinamika Psikologis Anak Pondok Cilik Maktab Nubdzatul bayan AlMajidiyah Palduding Plakpak Pegantenan Pamekasan. Tesis Tidak Diterbitkan.

Hariyanto. (2010). Tahap Perkembangan Psikosesksual Sigmund Freud. Retrieved Januari Sabtu, 2021, from http://belajarpsikologi.com

Jones, Richard Nelson. 2011. Teori dan praktik Konseling dan psikoterapi edisi keempat. Yogyakarta: Pustaka Belajar

Ma'arif, Syamsul. 2015. Pesantren Inklusif berbasis Kearifan Lokal. Yogyakarta: Kaukaba Dipantara

Muniroh, S. M. (2014 Vol. 1). Psikologi Santri Anak Usia Dini. 146-147.

Nurani, Y. (2013). Konsep Dasar Anak Usia Dini. Jakarta: Pt. Indeks.

Prasetiawan, A. Y. (2019). Perkembangan Golden Age Dalam Perspektif Pendidikan Islam. Jurnal Pendidikan dan pembelajaran Dasar Universitas Jenderal Soedirman, Volume 6 Nomor 1.

Rahman, H. (2005). Konsep Dasar Pendidikan Anak Usia Dini. Yogyakarta: PGTKI Press.

Santrock, J. W. (2012). Life Span Development: Perkembangan Masa Hidup Edisi Ketiga belas Jilid 1. Jakarta: Gelora Aksara Pratama.

Scaverian, J. (2011 ). Boarding School Syndrom: Broken Attacment a Hidden Trauma. British Journal Of Psycotherapy, Volume 27 Issue 2

Wuryantari, Tina. 2015. Hubungan antara Attachment Objek Pengganti dengan Tempramen pada Anak Usia Dini 4-6 Tahun di Lingkungan Sikunir Kelurahan Bergaslor Kecamatan Bergas. Skripsi tidak diterbitkan. 